\section{Patterns in the use of medicines by university students in Maputo, Mozambique}

\author{
Padrão de utilização de medicamentos por \\ estudantes de uma universidade de Maputo, \\ Moçambique
}

\footnotetext{
${ }^{1}$ Faculdade de Medicina, Universidade do Porto, Porto, Portugal.

2 Instituto Superior de Ciências e Tecnologia de Moçambique, Maputo, Moçambique.

3 Instituto Superior de Ciências da Saúde-Norte, Gandra, Portugal.

Correspondence R. Lucas

Laboratório de Higiene e Epidemiologia, Faculdade de Medicina, Universidade do Porto.

Alameda Prof. Hernâni Monteiro 4200-319, Porto, Portugal.

rlucas@med.up.pt
}

\begin{abstract}
Patterns in the use of medicines are expected to reflect distinct health features between populations. This study aimed to describe the self-reported use of medication by a sample of university students in Maputo, Mozambique. We conducted a survey of 797 students in a private university in Maputo. Participants completed a questionnaire including socio-demographic data and pattern of medication use in the preceding month. Information was collected on the number and names of drugs, duration of use, and prescription. The drugs were grouped according to therapeutic indication. In the previous month, 56\% of students had used at least one pharmaceutical drug, with higher prevalence for women (65.2\% vs. 42.2\%) and men attending health-related courses (67.4\% vs. 53.2\%). The most commonly used medicines were anti-inflammatory/analgesic drugs (62.2\%), anti-infectives (25.9\%), and vitamins/minerals (13.6\%). The most frequently used single drugs were paracetamol (42.8\%), amoxicillin (12.6\%), and ibuprofen (8.4\%). Duration of use was lowest for anti-inflammatory/analgesic drugs and highest for oral contraceptives. Use of medication by Mozambican students was similar to that observed in other university populations.
\end{abstract}

Drug Utilization; Drugs with Prescription; Students

\author{
Raquel Lucas 1 \\ Nuno Lunet 1,2 \\ Rui Carvalho 1,3 \\ Júlio Langa 2 \\ Marília Muanantatha 2 \\ Lucien-Pierre Nkunda 2 \\ Henrique Barros 1
}

\section{Introduction}

In the last twenty years the World Health Organization (WHO) has specifically emphasized the availability of essential drugs as a health indicator in developing countries 1. Social, economic, and health dynamics shape patterns in the use of medicines. In developing economies, social class inequalities can have an additional impact on expanding the right to access to medicines and their rational use 2 .

Mozambique has a population of nearly 20 million 3; the infant mortality rate is 124 per 1,000 live births and life expectancy at birth is 46.7 years 4 . Patterns in the use of medication by the general population are expected to reflect these health features. The description and evaluation of the use of medicines by African populations have mainly addressed specific therapeutic classes such as antiretroviral drugs and oral contraceptives 5,6. Patterns in the use of antimalarial drugs have also been studied in several African countries 7,8,9. Most of these studies have described samples from the deprived general population, reflecting the local burden of major health problems and needs, particularly considering perinatal disorders, malaria, and diarrheal diseases, the leading causes of mortality in recorded and autopsied deaths in 1994 10. The burden of disease associated with AIDS is increasing, as suggested by an expected 15-year decrease in life expectancy due to AIDS from 1999 to 201011. 
Identification of patterns in the use of medicines by university students would provide an insight into the utilization of this health technology by a more privileged segment of the population. Additionally, as a result of this group's increased access to medicines and health information, such knowledge would ultimately help define strategies for promoting the rational use of medicines by the general population.

Use of medicines by samples of students has been studied in several European, American, and Asian countries, naturally focusing on self-medication as an issue with public health implications $12,13,14,15,16,17$. However, research on African university students has focused more on the use of alcohol and illicit drugs 19,20 than pharmaceutical drugs, with the exception of the specific setting of a student's health service in Zimbabwe 18 .

Self-reported use of pharmaceutical drugs by a sample of university students in Maputo, Mozambique, provided a unique opportunity to investigate prescription drug use beyond the data available on oral contraceptives from the 2003 National Demographic and Health Survey ${ }^{4}$. The current study thus aimed to describe the use of medication in the previous 30 days in a sample of university students in Maputo.

\section{Methods}

We conducted a cross-sectional survey of students enrolled at a private university in Maputo, selected so as to comprise a large number of students and a relatively wide range of courses, encompassed in a single campus. The university had a total of nearly 1,500 students enrolled in computer engineering, accounting and auditing, business administration, dentistry, sociology, public administration, pharmacy, and law.

In early 2004, 47 of the 55 classes in the institution were systematically approached, comprising 829 students, distributed among all the daytime classes and 21 of 26 night classes. In order to shorten the data collection period, a one-week time frame was set to synchronize the period relating to responses. During this time frame, absenteeism and schedule constraints prevented approaching all the classes and all students in each class. Additionally, 32 students (3.9\%) refused to participate. The above-mentioned losses and refusals accounted for the final sample $(n=797)$, representing approximately $50 \%$ of the entire student body.

Students who agreed to participate were asked to complete a self-administered questionnaire during class with professors' consent. The 13-item questionnaire covered socio-demo- graphic information, use of medication during the previous 30 days, and lifetime use of antimalarial drugs.

Use of any medication in the previous month was assessed with the closed question "In the last month, did you use any medicine (including pills, capsules, injections, ointments, syrups, etc.)?”. If the answer was yes, subjects were asked to complete an open-ended table with the following information for each drug: brand or generic name, duration of treatment, self-medication (including pharmacy-counseled) versus physician-prescription, and intended purpose.

Instructions for completion of the questionnaire included examples of pharmaceutical drugs for each group, namely analgesics, steroidal and non-steroidal anti-inflammatory drugs, antihistamines, laxatives, vitamins, oral contraceptives, and anti-infectives.

Each medicine was coded to the corresponding level of WHO Anatomical Therapeutic Chemical classification (ATC) 21. For purposes of analysis, the degree of specificity within this classification was chosen as appropriate according to the extent of information obtained. Classes were flexibly combined to assemble similar therapeutic indications. As a result, the following larger groups were considered: anti-inflammatory and anti-rheumatic drugs, non-steroids (M01A) plus paracetamol (N02BE01); anti-infectives for systemic use (J); antimalarials (P01B); vitamins (A11) plus minerals (A12), excluding iron preparations (B03A); and hormonal contraceptives for systemic use (G03A). An additional group included medicines for women's health conditions, comprising hormonal contraceptives and iron preparations or analgesics when part of reproductive health management, as stated by the participants.

Subjects were grouped for analysis according to enrollment in health-related versus nonhealth-related courses, the former including Pharmacy and Dentistry. Proportions of users and non-users of medication were compared according to gender, age, course, and class period using $\chi^{2}$ or Fisher exact non-parametric tests, as appropriate, at a $95 \%$ confidence level. Data analysis used Stata 8.0 software (Stata Corp., College Station, U.S.A.).

The study allowed estimating a prevalence of utilization of medicines as low as $5 \%$, with $1 \%$ precision and $95 \%$ confidence level.

The National Ethics Committee of Mozambique approved the study protocol.

Students were asked to read an informed consent form stating the study objectives and data collection methods, in agreement with the Declaration of Helsinki. Only students who 
signed the informed consent form were allowed to participate and were asked to complete the questionnaire.

\section{Results}

Among the 797 respondents, median age was 23 years (18-51), with $58.7 \%$ females and $18.3 \%$ attending health-related courses.

Use of at least one pharmaceutical drug in the previous month was reported by $55.8 \%$ of subjects. Among users, the median number of medicines was one and the maximum seven.

Fifteen percent of women used at least one of the products for women's health as defined above, and $4.8 \%$ specifically reported taking oral contraceptives. Women used medicines more frequently than men $(65.2 \%$ vs. $42.2 \%, \mathrm{p}<0.001)$, even after excluding drugs related to reproductive health $(59.4 \%$ vs. $42 \%, \mathrm{p}<0.001)$.

Similar results were obtained for anti-inflammatory drugs/analgesics $(40.4 \%$ vs. $26 \%$, $\mathrm{p}<0.001)$, anti-infectives excluding antimalarials ( $17.8 \%$ vs. $9.7 \%, \mathrm{p}<0.05)$, and vitamins/minerals $(10.2 \%$ vs. $4.2 \%, \mathrm{p}<0.05)$. For use of antimalarials, no significant differences were found for gender $(6.9 \%$ in females vs. $5.2 \%$ in males, $\mathrm{p}=0.48)$ or type of university course $(9.3 \%$ for health-related vs. $4.5 \%$ for non-health-related, $\mathrm{p}=0.07$ ).

Male students in health-related courses used medicines more frequently ( $60 \%$ vs. $40.3 \%$, $\mathrm{p}<0.05$ ), but at a proportion similar to that estimated for women attending health-related courses ( $60 \%$ vs. $69.6 \%, \mathrm{p}=0.32)$. When considering specific groups of medicines, significant differences in utilization according to type of course were only observed for anti-inflammatory/analgesic drugs ( $44.4 \%$ vs. $32.5 \%$, $\mathrm{p}<0.05)$. There were no statistically significant differences across age groups or between daytime versus night classes (Table 1).

Among users of medicines, anti-inflammatory and analgesic drugs were the most frequently reported, followed by systemic anti-infectives, vitamins/minerals, oral contraceptives, and antimalarials. When analyzed individually, paracetamol, amoxicillin, and ibuprofen were the single most frequently used drugs $(42.8 \%$, $12.6 \%$ and $8.4 \%$, respectively).

The proportion of subjects using physicianprescribed medication was $35.7 \%$ for anti-inflammatory and analgesic drugs, $80.9 \%$ for antiinfectives, $78.2 \%$ for vitamin and mineral supplements, and $72.2 \%$ for oral contraceptives. The highest proportions of prescription treatment were for antimalarials (91.7\%) and iron supplements (100\%) (Table 2).
Women on oral contraceptives remained exposed to this medication throughout the entire recall period. For other drug groups, the longest median duration of use was for vitamins/minerals (median: 15 days; inter-quartile range or IQR: 7-30 days) followed by iron supplements (median: 15 days; IQR: 8-30 days), and anti-infectives, excluding antimalarials (median: 8 days; IQR: 7-15 days). Treatment was shorter for anti-inflammatory/analgesic drugs (median: 3 days; IQR: 1-7 days). Both paracetamol and ibuprofen had a median duration of treatment of 3 days, while treatment was longer for amoxicillin (median: 8 days) (Table 2).

\section{Discussion}

Fifty-six per cent of adult students in this sample recalled the use of at least one pharmaceutical drug during the previous month. The proportion was significantly higher in women and in men attending health-related courses. The students used mostly anti-inflammatory/analgesic drugs $(62.2 \%)$, anti-infectives other than antimalarials $(25.9 \%)$, and vitamin/mineral supplements (13.6\%).

In our study, although we approached students from all daytime and most night classes and the refusal rate was low, information was obtained from only half of the student body. Women were thus over-represented in the sample $(58.7 \%$ vs. $50 \%$ of total enrollment), which may have contributed to overestimation of the use of most medicines. We may also expect a slight overestimation in the use of medicines by men, since a proportionally larger number of male students in health-related courses were included. Median student age at this university (27 years), as collected from university statistics, was higher than in our sample, but these differences are not likely to affect our estimates, since no statistically significant association was observed between age and use of medicines.

The so-called "healthy worker effect" is another important limitation in the validity of our findings. In the present methodological approach, we collected data on campus, so that absent students were not sampled. Considering that poorer health may partially account for absenteeism, and that unhealthy status is associated with higher consumption of pharmaceuticals, our findings probably underestimate the actual use of medicines by this population group. In fact, poor health was probably a prior selective factor for entering the university in the first place. Although this type of bias could lead to underestimation of the overall prevalence of pharmaceu- 
Table 1

Prevalence of pharmaceutical drug use according to gender, age, and type of university course for the most frequently reported therapeutic classes used in the previous month by 797 university students in Maputo, Mozambique.

\begin{tabular}{|c|c|c|c|c|c|c|c|c|c|c|c|c|c|}
\hline & \multirow[t]{3}{*}{$n$ * } & \multicolumn{12}{|c|}{ Prevalence of pharmaceutical drug use } \\
\hline & & \multicolumn{2}{|c|}{$\begin{array}{c}\text { All } \\
\text { medicines }\end{array}$} & \multicolumn{2}{|c|}{$\begin{array}{l}\text { Anti- } \\
\text { inflammatory/ } \\
\text { Analgesic drugs }\end{array}$} & \multicolumn{2}{|c|}{$\begin{array}{c}\text { Anti- } \\
\text { infectives ** }\end{array}$} & \multicolumn{2}{|c|}{$\begin{array}{l}\text { Vitamins/ } \\
\text { Minerals }\end{array}$} & \multicolumn{2}{|c|}{ Antimalarials } & \multicolumn{2}{|c|}{$\begin{array}{c}\text { Oral } \\
\text { contraceptives }\end{array}$} \\
\hline & & $\mathrm{n}$ & $\%$ & $\mathrm{n}$ & $\%$ & $\mathrm{n}$ & $\%$ & $\mathrm{n}$ & $\%$ & $\mathrm{n}$ & $\%$ & $\mathrm{n}$ & $\%$ \\
\hline All subjects & 766 & 428 & 55.8 & 266 & 34.7 & 111 & 14.5 & 58 & 7.6 & 43 & 5.6 & 22 & 4.8 \\
\hline \multicolumn{14}{|l|}{ Gender } \\
\hline Male & 308 & $130 * * *$ & 42.2 & $80 * \star \star$ & 26.0 & $30 \#$ & 9.7 & $13 \#$ & 4.2 & 21 & 6.9 & - & - \\
\hline Female & 443 & 289 & 65.2 & 179 & 40.4 & 79 & 17.8 & 45 & 10.2 & 23 & 5.2 & 22 & 4.8 \\
\hline \multicolumn{14}{|l|}{ Age (years) } \\
\hline $18-25$ & 432 & 246 & 56.9 & 158 & 36.6 & 55 & 12.7 & 34 & 7.9 & 23 & 5.3 & 9 & 3.3 \\
\hline $26-35$ & 146 & 76 & 52.0 & 43 & 29.4 & 27 & 18.5 & 8 & 5.5 & 10 & 6.6 & 6 & 7.8 \\
\hline$\geq 36$ & 122 & 65 & 53.3 & 43 & 35.2 & 20 & 16.4 & 9 & 7.4 & 7 & 6.2 & 4 & 7.0 \\
\hline \multicolumn{14}{|l|}{ Course } \\
\hline Health-related & 144 & $97 \#$ & 67.4 & $64 \#$ & 44.4 & 20 & 13.8 & 13 & 9.0 & 13 & 9.3 & 18 & 5.2 \\
\hline Non-health-related & 622 & 331 & 53.2 & 202 & 32.5 & 108 & 17.4 & 45 & 7.2 & 28 & 4.5 & 4 & 3.5 \\
\hline \multicolumn{14}{|l|}{ Class period } \\
\hline Daytime & 489 & 287 & 58.6 & 183 & 37.4 & 63 & 12.9 & 40 & 8.3 & 28 & 5.8 & 14 & 4.5 \\
\hline Night & 269 & 144 & 53.5 & 85 & 31.5 & 46 & 17.3 & 18 & 6.7 & 16 & 5.9 & 8 & 6.4 \\
\hline
\end{tabular}

* The number of subjects may not reflect the total $(n=766)$, due to missing data;

** Excluding antimalarials;

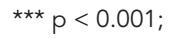

$\# p<0.05$.

Table 2

Medical prescription and duration of therapy for the most frequent therapeutic classes and pharmaceutical drugs used in the previous month by 797 university students in Maputo, Mozambique.

\begin{tabular}{lccc}
\hline & Medically-prescribed & Median (P25-P75 *) \\
duration (days) & \% & 35.7 & $3(1-7)$ \\
\hline Anti-inflammatory/Analgesic drugs & $\mathbf{n}$ & 34.3 & $3(1-5)$ \\
Paracetamol & 91 & 45.5 & $3(2-7)$ \\
Ibuprofen & 60 & 80.9 & $8(7-15)$ \\
Anti-infectives (excluding antimalarials) & 15 & 83.0 & $8(7-10)$ \\
Amoxicillin & 89 & 78.2 & $15(7-30)$ \\
Vitamins/Minerals & 44 & 100.0 & $15(8-30)$ \\
Iron supplements & 43 & 91.7 & $3(1-3)$ \\
Antimalarials & 21 & 72.2 & $30(30-30) * *$ \\
Oral contraceptives & 22 & 13 & \\
\hline
\end{tabular}

* Percentile 25-Percentile 75;

** In order to avoid non-response, questionnaire completion examples included oral contraceptives with an exposure period defined as daily. This example probably induced respondents to frame a 30-day duration of treatment. However, even considering that exposure periods for oral contraceptives are usually 21 days per month, the actual treatment may be considered to last the entire month. 
tical drug use and to inaccuracy in the evaluation of the relative weight of some pharmaceutical drugs or drug groups, it does not impair comparisons with studies conducted under similar conditions.

Overall prevalence of the use of medicines showed significant gender-related differences for every drug group except antimalarials. Conversely, the observed course-related prevalence of all-drug use is explained mainly by differences in the use of anti-inflammatory/analgesic drugs. Differences in the use of health care services and specific health knowledge may account for this gender and course-related prevalence.

Analogous studies in other countries (Table 3) showed similar prevalence of pharmaceutical drug use, with the exception of the $83 \%$ prevalence in a North American sample 22. In all of these studies, women tended to use medicines more frequently, as did students in health-related course 23,24. However, Mozambican stu- dents used antimalarial and other anti-infective medications more often. These differences reflect distinct disease patterns between populations, namely regarding endemic malaria, but may also relate to differences in data collection instruments. In addition, two previous studies only included students attending health-related courses, which probably produced more accurate recall 23,25 .

An important finding is that psychotropic drugs are practically absent from our data. Similar results have been described in a Brazilian sample of students, in which the non-medical use of psychotropic medicines in the previous month varied from $0.2 \%$ for barbiturates to $2.1 \%$ for tranquilizers 17 . In Cape Town, $18 \%$ of fifth-year medical students reported using these substances in their pre-examination period 19 . A French study found that $28 \%$ of female and $14 \%$ of male students had used psychotropic drugs 12 . In the present study, the lack of an ex-

Characteristics and results of studies on the prevalence of use of medicines by different university populations.

\begin{tabular}{|c|c|c|c|c|c|c|c|c|}
\hline Study & Year & $\begin{array}{l}\text { Country } \\
\text { (sample) }\end{array}$ & $\begin{array}{l}\text { Subjects in } \\
\text { health- } \\
\text { related } \\
\text { courses }\end{array}$ & $\begin{array}{l}\text { Recall } \\
\text { period }\end{array}$ & $\begin{array}{c}\text { Preva- } \\
\text { lence (\%) }\end{array}$ & Females vs. males & $\begin{array}{l}\text { Health vs. non- } \\
\text { health-related } \\
\text { courses }\end{array}$ & $\begin{array}{l}\text { Most frequent } \\
\text { classes of } \\
\text { pharmaceutical } \\
\text { drugs }\end{array}$ \\
\hline Lopez et al. 23 & 1997 & $\begin{array}{c}\text { Spain } \\
(\mathrm{N}=380)\end{array}$ & $\begin{array}{c}100 \% \\
\text { (Pharmacy) }\end{array}$ & $\begin{array}{l}\text { Previous } \\
\text { two weeks }\end{array}$ & 64.2 & $\begin{array}{c}68.5 \% \text { vs. } 56.5 \\
\quad(p<0.05)\end{array}$ & NA & $\begin{array}{l}\text { Oral contraceptives; } \\
\text { NSAIDs; antibiotics }\end{array}$ \\
\hline Cabrita et al. 24 & 2001 & $\begin{array}{l}\text { Portugal } \\
(\mathrm{N}=1.147)\end{array}$ & $18.1 \%$ & $\begin{array}{l}\text { Previous } \\
\text { two weeks }\end{array}$ & 57.0 & $\begin{array}{c}62.9 \% \text { vs. } 42.6 \% \\
(p<0.001)\end{array}$ & $\begin{array}{c}\text { More frequent in } \\
\text { health-related courses } \\
\text { (NS), especially } \\
\text { pharmacy (NS) }\end{array}$ & $\begin{array}{c}\text { Oral contraceptives } \\
(7.8 \%) ; \text { NSAIDs } \\
(37.4 \%) ; \\
\text { antibacterials (5.9\%) }\end{array}$ \\
\hline Marques-Vidal et al. 25 & 2005 & $\begin{array}{l}\text { Portugal } \\
(N=588)\end{array}$ & $100 \%$ & $\begin{array}{l}\text { Previous } \\
\text { month }\end{array}$ & 48.0 & $\begin{array}{c}52 \% \text { vs. } 41 \% \\
(p=0.001)\end{array}$ & $\begin{array}{l}\text { Pharmacy vs. other } \\
\text { (no statistically } \\
\text { significant } \\
\text { difference } \\
\text { further } \\
\text { specified) }\end{array}$ & $\begin{array}{l}\text { Oral contraceptives } \\
\qquad \begin{array}{l}(12.5 \%) ; \\
\text { NSAIDs }(30 \%) ; \\
\text { antibiotics }(8 \%)\end{array}\end{array}$ \\
\hline Acoccela et al. 22 & 2005 & $\begin{array}{l}\text { United States } \\
\qquad(\mathrm{N}=183)\end{array}$ & NS & $\begin{array}{l}\text { Previous } \\
\text { week }\end{array}$ & $\begin{array}{l}83.1 \text { (self- } \\
\text { medication) }\end{array}$ & $\begin{array}{c}87.5 \% \text { vs. } 70.2 \% \\
\quad(p=0.006)\end{array}$ & NS & $\begin{array}{c}\text { Analgesics }(68.3 \%) ; \\
\text { cold/allergy } \\
\text { medication }(33.3 \%)\end{array}$ \\
\hline Present study & 2004 & $\begin{array}{l}\text { Mozambique } \\
\qquad(\mathrm{N}=797)\end{array}$ & $18.3 \%$ & $\begin{array}{l}\text { Previous } \\
\text { month }\end{array}$ & 55.8 & $\begin{array}{l}\text { Non-health courses: } \\
\begin{array}{c}63.8 \% \text { vs. } 40.3 \% \\
(p<0.001) \\
\text { health courses: } \\
69.6 \% \text { vs. } 60.0 \% \\
(p=0.32)\end{array}\end{array}$ & $\begin{array}{c}67.4 \% \text { vs. } 53.2 \% \\
(p<0.002)\end{array}$ & $\begin{array}{l}\text { Oral contraceptives } \\
\qquad(4.8 \%) ; \\
\text { NSAIDs (34.7\%); } \\
\text { antimalarials }(5.6 \%) ; \\
\text { other anti-infectives } \\
(14.5 \%)\end{array}$ \\
\hline
\end{tabular}

NS: not specified; NA: not applicable; NSAIDs: non-steroidal anti-inflammatory drugs. 
ample of these substances in the questionnaire instructions may help explain our results.

Regarding vitamin/mineral supplements, which were listed among the questionnaire examples, we found a relatively low prevalence of use. North American medical students used these medications more frequently (53\% for multivitamin/multimineral supplements, $23 \%$ for calcium, and $22 \%$ for other vitamin/mineral supplements) 26 . Another study in Florida showed $47 \%$ prevalence in the use of vitamin and mineral supplements in the previous two weeks 27 . The rate was also higher among Korean 17 and 18year-olds (54\%) 28 .

Prevalence of self-medication in our sample was relatively low, especially compared to the 94\% estimate for cold preparations, analgesics, and anti-inflammatory drugs among university students in Hong Kong 13. Additionally, pharmacy and medical students in Croatia frequently reported self-medication at home with non-steroidal anti-inflammatory drugs (NSAIDs) (88\%) and antibiotics (37\%) 14 . Moreover, in a population-based Sudanese sample, $74 \%$ of adults had used antibiotics or antimalarials without a medical prescription within one month prior to the study ${ }^{8}$. A high prevalence of self-treatment of malaria has also been described in Kenya, where $60 \%$ of episodes of febrile illness were treated at home 9 . In keeping with these findings, poor knowledge on self-medication was found in Bahrain 16 , and incorrect beliefs about antibiotic use among college students were highly prevalent in Turkey 15 and North America 29.

Overall, the median period of use for each group of medicines appears to match the length of treatment for the most common therapeutic regimens. For anti-infectives (excluding antimalarials), most subjects were under treatment for a week or more, suggesting high treatment adherence in this population.

Prevalence of oral contraceptive use in our sample was relatively low (4.8\%) compared to European studies and the $16.8 \%$ rate in a less educated population in Maputo (only 25\% of whom had secondary level education $)^{4}$. A study published in 1995 showed $23.5 \%$ prevalence of oral contraceptive use among Nigerian university students 6 , nearly five times that of our sample. Recall bias should not be expected to play a specific role in this study, since the questionnaire contained examples of the most widely used drug classes, including oral contraceptives, subjects were well educated, and the time frame was narrow. The difference might be explained by selective underreporting of this drug group due to cultural or social constraints, even though the questionnaire was anonymous. Meanwhile, a more likely hy- pothesis is that differences show that university students do not represent the general Mozambican population, namely because of their level of schooling and social and cultural backgrounds. The fact that our sample was drawn from a private university further limits the representativeness of the country's university population.

In population groups with presumed access to medication beyond essential drugs, as in the case of university students, the analysis of selfreported pharmaceutical drug use has the advantages of including both self-prescribed and physician-prescribed drugs and providing a realistic estimate of actual consumption patterns 30 . As expected, the proportion of self-prescribed use of NSAIDs was high (64.3\%) compared to the rates for antibiotics (19.1\%), antimalarials (8.3\%), or iron supplements $(0 \%)$. Legislation, along with awareness of therapeutic indications and safety profiles, can account for these findings, but national health policies regarding reimbursements may also be part of the explanation.

\section{Conclusion}

Prevalence of pharmaceutical drug use during the previous month by Mozambican university students was similar to recent Southern European findings concerning gender differences, therapeutic classes, and individual drugs. These results suggest similar utilization of medicines for managing minor health problems in university students across populations, regardless of overall access to medicines and professional-level information. However, some situations present specific local weights, and contraceptive use may reflect important cultural constraints. 


\section{Resumo}

O padrão de utilização de medicamentos nas populações pode refletir diferenças na sua saúde. O objetivo deste estudo foi descrever o uso de medicamentos numa população universitária em Maputo, Moçambique. Foram avaliados 797 estudantes de uma universidade privada. Os participantes preencheram um questionário que incluía variáveis sócio-demográficas e de utilização de medicamentos no mês anterior. Foi colhida informação relativa ao número e nome dos medicamentos, duração da utilização e prescrição. Os fármacos foram classificados conforme a indicação terapêutica. Entre os estudantes, 56\% tinham utilizado pelo menos um fármaco, com maior prevalência nas mulheres (65,2\% vs. $42,2 \%$ ) e nos homens que freqüentavam cursos de saúde (67,4\% vs. 53,2\%). Os estudantes usaram principalmente antiinflamatórios/analgésicos (62,2\%), anti-infecciosos (25,9\%) e vitaminas/minerais (13,6\%). Os fármacos mais freqüentemente utilizados foram paracetamol (42,8\%), amoxicilina $(12,6 \%) e$ ibuprofeno $(8,4 \%)$. A duração da terapêutica foi menor para antiinflamatórios/analgésicos e maior para contraceptivos orais. O padrão de utilização de medicamentos por estudantes moçambicanos foi semelhante ao observado noutras populações universitárias.

Uso de Medicamentos; Medicamentos com Prescrição; Estudantes

\section{References}

1. World Health Organization. The rational use of drugs. Geneva: World Health Organization; 1987.

2. Ratanawijitrasin S, Soumerai SB, Weerasuriya K. Do national medicinal drug policies and essential drug programs improve drug use? A review of experiences in developing countries. Soc Sci Med 2001; 53:831-44.

3. Instituto Nacional de Estatística. Portal do Instituto Nacional de Estatística de Moçambique. http:// www.ine.gov.mz (accessed on 18/May/2006).

4. Instituto Nacional de Estatística. Inquérito demográfico e de saúde 2003 (relatório preliminar). Maputo: Instituto Nacional de Estatística; 2004.

5. Marazzi MC, Bartolo M, Emberti-Gialloreti L, Germano P, Guidotti G, Liotta G, et al. Improving adherence to highly active anti-retroviral therapy in Africa: the DREAM programme in Mozambique. Health Educ Res 2006; 21:34-42.

\section{Contributors}

R. Lucas contributed to the data analysis and interpretation and production of the first version of the manuscript. N. Lunet contributed to the study conceptualization and design, data analysis, and critical review of the manuscript. R. Carvalho contributed substantially to the data analysis and interpretation. J. Langa, M. Muanantatha, and L.-P. Nkunda contributed substantially to the data acquisition. H. Barros critically reviewed the manuscript for content. All the authors approved the final version for publication.
6. Adinma JI, Okeke AO. Contraception: awareness and practice amongst Nigerian tertiary school girls. West Afr J Med 1995; 14:34-8.

7. Ball D, Jeffery M. Use of antimalarial drugs in Zimbabwe. Cent Afr J Med 2001; 47:164-5.

8. Awad A, Eltayeb I, Matowe L, Thalib L. Self-medication with antibiotics and antimalarials in the community of Khartoum State, Sudan. J Pharm Pharm Sci 2005; 8:326-31.

9. Ruebush TK, Kern MK, Campbell CC, Oloo AJ. Selftreatment of malaria in a rural area of western Kenya. Bull World Health Organ 1995; 73:229-36.

10. Dgedge M, Novoa A, Macassa G, Sacarlal J, Black J, Michaud C, et al. The burden of disease in Maputo City, Mozambique: registered and autopsied deaths in 1994. Bull World Health Organ 2001; 79:546-52. 
11. Centro de Estudos de População/Instituto Nacional de Estatística/Ministério da Saúde/Ministério do Plano e Finanças. Impacto demográfico do HIV/SIDA em Moçambique. Maputo: Centro de Estudos de População, Universidade Eduardo Mondlane; 2000.

12. Ledoux S, Choquet M. Psychotropic drug use in adolescence: why more girls? Study of a sample of 12-20-year-old students in Haute-Marne (France). Rev Epidemiol Sante Publique 1994; 42:216-23.

13. Lau GS, Lee KK, Luk CT. Self-medication among university students in Hong Kong. Asia Pac J Public Health 1995; 8:153-7.

14. Aljinovic-Vucic V, Trkulja V, Lackovic Z. Content of home pharmacies and self-medication practices in households of pharmacy and medical students in Zagreb, Croatia: findings in 2001 with a reference to 1977. Croat Med J 2005; 46:74-80.

15. Buke C, Hosgor-Limoncu M, Ermertcan S, Ciceklioglu M, Tuncel M, Kose T, et al. Irrational use of antibiotics among university students. J Infect 2005; 51:135-9.

16. James H, Handu SS, Al Khaja KA, Otoom S, Sequeira RP. Evaluation of the knowledge, attitude and practice of self-medication among first-year medical students. Med Princ Pract 2006; 15:270-5.

17. Dal Pizzol TS, Branco MMN, Carvalho RMA, Pasqualotti A, Maciel EN, Migott AMB. Uso nãomédico de medicamentos psicoativos entre escolares do ensino fundamental e médio no Sul do Brasil. Cad Saúde Pública 2006; 22:109-15.

18. Bvochora JF, Kasilo OM, Nhachi CF. Disease pattern and prescribing at the University of Zimbabwe student health service, 1987-1991. Cent Afr J Med 1993; 39:88-95.

19. Flisher AJ. Pre-examination psychotropic drug use by 5 th-year medical students at the University of Cape Town. S Afr Med J 1989; 76:541-3.
20. Nevadomsky JJ. Drug use among Nigerian university students: prevalence of self-reported use and attitudes to use. Bull Narc 1985; 37:31-42.

21. World Health Organization Collaborating Centre for Drug Statistics Methodology/Nordic Council on Medicines. Guideline for ATC classification. Oslo: World Health Organization; 1990.

22. Acocella CM. Using diaries to assess nonprescription drug use among university students. J Drug Educ 2005; 35:267-74

23. López J, González M. Utilización de medicamentos por estudiantes de farmacia de la Universidad de Granada. Farm Clin 1997; 14:90-7.

24. Cabrita J, Ferreira HS, Iglesias P, Baptista TM, Rocha E, Silva LA, et al. Study of drug utilization among students at Lisbon University in Portugal. Pharmacoepidemiol Drug Saf 2002; 11:333-4.

25. Marques-Vidal P. Medicine usage and handling in a sample of Portuguese students. Revista da Faculdade de Medicina de Lisboa 2005; 10:279-84.

26. Spencer EH, Bendich A, Frank E. Vitamin and mineral supplement use among US medical students: a longitudinal study. J Am Diet Assoc 2006; 106:1975-83.

27. Ranelli PL, Dickerson RN, White KG. Use of vitamin and mineral supplements by pharmacy students. Am J Hosp Pharm 1993; 50:674-8.

28. Kim SH, Han JH, Zhu QY, Keen CL. Use of vitamins, minerals, and other dietary supplements by 17- and 18-year-old students in Korea. J Med Food 2003; 6:27-42.

29. Zoorob RJ, Larzelere MM, Malpani S, Zoorob R. Use and perceptions of antibiotics for upper respiratory infections among college students. J Fam Pract 2001; 50:32-7.

30. Le Grand A, Hogerzeil HV, Haaijer-Ruskamp FM. Intervention research in rational use of drugs: a review. Health Policy Plan 1999; 14:89-102.

\footnotetext{
Submitted on $27 /$ Nov/2006

Final version resubmitted on 05/Mar/2007

Approved on 13/Mar/2007
} 